\title{
DISRUPTION OF HYPOTHALAMUS-PITUITARY-LIVER-GONADS AXIS IN THE ENDANGERED Girardinichthys viviparus EXPOSED TO ENVIRONMENTALLY RELEVANT CONCENTRATIONS OF A MIXTURE OF METALS AND WITH 17 $\alpha$-ETHYNIL ESTRADIOL
}

\author{
Hugo F. OLIVARES-RUBIO, Ricardo DZUL-CAAMAL, Minerva NÁJERA-MARTÍNEZ and \\ Armando VEGA-LÓPEZ*
}

Laboratorio de Toxicología Ambiental, Escuela Nacional de Ciencias Biológicas, Instituto Politécnico Nacional. Avenida Wilfrido Massieu, Unidad Profesional Zacatenco, Ciudad de México, México, C. P. 07320

*Corresponding author: avegadv@yahoo.com.mx

(Recieved March 2016; accepted September 2016)

Key words: gonadotropins, estradiol, vitellogenin, metallothionein, sex-linked response

\begin{abstract}
Girardinichthys viviparus is an endemic and endangered Mexican fish species with matrotrophic viviparity that only inhabits in some polluted water bodies in the Valley of Mexico. In the current study, G. viviparus of both sexes were exposed for 21 days to a mixture of metals with relevant environmental concentrations (T1) and to the same mixture spiked with $25 \mathrm{ng}$ of $17 \alpha$-ethynil estradiol $\left(\mathrm{EE}_{2}\right) / \mathrm{L}(\mathrm{T} 2)$. Some biomarkers involved in endocrine disruption of the hypothalamus-pituitary-liver-gonads axis such as gonadotropins I and II (GtH I and GtH II, respectively), and estradiol $\left(E_{2}\right)$ concentrations in the head and gonads were measured. Vitellogenin (VTG) in the liver and gonads, and metallothionein (MT) in the head, liver and gonads were assessed. Increases of GtH I and decreases in GtH II, and alterations of $\mathrm{E}_{2}$ in the head and gonads were found in fish treated with T1 and T2. Higher content of hepatic and gonadal VTG only in fish treated with T2 was detected. MT was notably induced by T2; however, a time-dependent MT reduction was observed. In both treatments, the hypothalamic-pituitary control point was most affected and their alterations were documented by gonadal and head content of $\mathrm{E}_{2}$. In female fish, it is most likely that endogenous levels of $\mathrm{E}_{2}$ diminished the alterations elicited by $\mathrm{EE}_{2}$ on this control point of the axis in contrast with male fish. The endocrine disruption of this fish species is a dynamic and complex process.
\end{abstract}

Palabras clave: gonadotropinas, estradiol, vitelogenina, metalotioneínas, respuesta ligada al sexo

\section{RESUMEN}

Girardinichthys viviparus es un pez mexicano endémico y en peligro de extinción con viviparidad matrotrófica que sólo habita en algunos cuerpos de agua contaminados del Valle de México. En este estudio, especimenes de G. viviparus de ambos sexos fueron expuestos durante 21 días a una mezcla de metales a concentraciones ambientalmente relevantes (T1) y a la misma mezcla enriquecida con $25 \mathrm{ng}$ de $17 \alpha$-etinil estradiol $\left(\mathrm{EE}_{2}\right) / \mathrm{L}(\mathrm{T} 2)$. En la cabeza y las gónadas se midieron biomarcadores implicados en el eje endocrino sexual hipotálamo-pituitaria-gónadas-hígado, así como las concentraciones de estradiol $\left(\mathrm{E}_{2}\right)$, gonadotropina I y II (GtH I y GtH II, respectivamente). En el 
hígado y las gónadas se evaluó la vitelogenina (VTG) y en la cabeza, el hígado y las gónadas los niveles de metalotioneínas (MT). En la cabeza y las gónadas de los peces expuestos a ambos tratamientos se observaron aumentos de la GtH I, disminuciones de GtH II y alteraciones de $\mathrm{E}_{2}$. Solamente en los peces expuestos al T2 se encontraron incrementos hepáticos y gonadales de VTG. Las MT fueron inducidas particularmente por el T2. Sin embargo, se observó una reducción dependiente del tiempo. En ambos tratamientos, el punto de control hipotálamo-pituitaria fue el más afectado y sus alteraciones fueron evidenciadas por los contenidos de $\mathrm{E}_{2}$. En contraste con los machos, en hembras es probable que los niveles endógenos de $\mathrm{E}_{2}$ disminuyeran por las alteraciones provocadas por $\mathrm{EE}_{2}$ en este punto de control del eje. La disrupción endocrina de esta especie de pez es un proceso dinámico y complejo.

\section{INTRODUCTION}

In teleost fish, the reproduction is regulated by the hypothalamus-pituitary-liver-gonads (HPLG) axis (Janz and Weber 2000). In response to external and internal stimuli, the gonadotropin-releasing hormone $(\mathrm{GnRH})$ is liberated from hypothalamus to the gonadotropic cells stimulating the release of gonadotropins (GtHs) (Bailhache et al. 1994, Rempel and Schlenk 2008). Both gonadotropins GtH I and GtH II could bind to specific receptors in the testis and ovaries during the final stages of gamete maturation for the synthesis of steroid hormones as $17 \beta$-estradiol $\left(E_{2}\right)$ in females and 11-ketotestosterone in males (Janz and Weber 2000). Steroid hormones are responsible for most biological activities such as the involvement in the control of sexual differentiation, maturation and reproduction (Diotel et al. 2010). The process of estrogen biosynthesis is catalyzed by cytochrome P450 aromatase from androgens (Diotel et al. 2010, Coumailleau et al. 2015). In the other hand, in fish the vitellogenin (VTG), a precursor of the oocyte yolk is synthesized in the liver by the activation of estrogen receptor (ER) mainly by $\mathrm{E}_{2}$ (Sumpter and Jobling 1995).

In the aquatic ecosystems, many endocrine disrupting compounds (EDCs) can be found, such as the case of $17 \alpha$-ethynil estradiol $\left(\mathrm{EE}_{2}\right)$ used in oral contraceptives with high estrogenic potency (Shanle and $\mathrm{Xu}$ 2011). Many studies in fish have documented that $\mathrm{EE}_{2}$ possesses high affinity with $\mathrm{ER}$ and could increase the VTG expression and synthesis in both male and female fishes (Folmar et al. 2000, Rose et al. 2002, van den Belt et al. 2003).

A similar case occurs with heavy metals, which can alter the normal function of the gonads in fish (Amutha and Subramanian 2013), inducing a reduction in the size of the gonads (Luszczek-Trojnar et al. 2014), disrupting the reproductive neuroendocrine function (Khan and Thomas 2000) and some metals are involved in the activation of ER through "zinc fingers" at pre-transcriptomic level (Darbre 2006). In the environment, it is possible that some metals could alter the HPLG axis (Simmons et al. 2014, Olivares-Rubio et al. 2015). Divalent metals increase the expression of VTG in the western mosquitofish (Gambusia affinis) (Huang et al. 2014) and potentiating the estrogenic capacity of $\mathrm{E}_{2}$ on goldfish (Carassius auratus) hepatocytes (Chang et al. 2011) that are essential for VTG synthesis such as $\mathrm{Zn}$ and $\mathrm{Ca}$ (Falchuk and Montorzi 2001). Several mechanisms are involved in the binding of metals to cellular components such as the metallothioneins (MT) synthetized by animal cells (Palacios et al. 2011, Sears 2013). However, a lack of information prevails about the possible toxic effects of metals alone and in mixture, and in the presence of exogenous estrogens in the performance of HPLG axis. This information is relevant because in the aquatic environment, the fish species could be exposed to the complex mixture of pollutants including metals and xeno-estrogens capable to disrupt this axis at different points of control.

The mexcalpique (Girardinichthys viviparus) is an endemic and critically endangered fish species belonging to family Goodeidae. This fish species inhabits only in some water bodies in the Valley of Mexico. The mexcalpique possess a matrotrophic viviparity as a reproductive strategy (Vega-López et al. 2007). Recently, our research team found that wild G. viviparus inhabitant of two lakes with different degree of pollution in Mexico City suffers a noticeable disruption of the sexual endocrine axis, mainly in male fish influenced by cyp 1A1 activity and by $\mathrm{EE}_{2}$ exposure (Olivares-Rubio et al. 2015). In addition, negative effects of $\mathrm{Pb}$ in the HPLG axis were documented (Olivares-Rubio et al. 2015). Therefore the aim of this study was to assess a battery of biomarkers involved in the HPLG axis in mexcalpique treated with environmental relevant concentrations of mixture of metals and with the same mixture of metals spiked with $25 \mathrm{ng} \mathrm{EE}_{2} / \mathrm{L}$ at 7, 14 and 21 days 
of exposure. This concentration of $\mathrm{EE}_{2}$ was chosen because the maximum contents of hepatic VTG were found at this treatment after 7,14 and 21 days of exposure in this fish species (data not published). In the head, the content of GtH I, GtH II, $\mathrm{E}_{2}$ and MT were measured to evaluate the alteration on hypothalamus-pituitary control point. In the liver, the content of VTG and MT as biomarker of estrogenic response and binding of metals, respectively, were quantified. In the gonads the content of GtH I, GtH II, $E_{2}$, and of VTG were assessed since the gonads are a target tissue of gonadotropins and are a source of $E_{2}$ production and VTG storage in female fish.

\section{MATERIAL AND METHODS}

\section{Fish species and experimental design}

Specimens of Girardinichthys viviparus born in laboratory within the age of 8-10 months (24.4-25.3 and 42.3-45.1 $\mathrm{mm}$ of standard length for males and females, respectively) were used. These differences in the size among sexes of this fish species are due to its sexual dimorphism (Vega-López et al. 2007, Sedeño-Díaz and López-López 2009). Fishes were separated by sex, one month before the experiments to avoid the courtship and activation of the endocrine sexual axis. The exposure conditions were the following: $i$ ) Treatment 1 (T1), a mixture of metals at environmentally relevant concentrations found in the lakes of $2^{\text {nd }}$ Section of Chapultepec Park $(\mathrm{Cu}=0.4 \mathrm{mg} / \mathrm{L}, \mathrm{Fe}=0.9 \mathrm{mg} / \mathrm{L}, \mathrm{Mn}=0.3 \mathrm{mg} / \mathrm{L}$, $\mathrm{Pb}=0.13 \mathrm{mg} / \mathrm{L}$ and $\mathrm{Zn}=0.15 \mathrm{mg} / \mathrm{L}$ ) (Olivares-Rubio et al. 2015), ii) Treatment 2 (T2), the same mixture

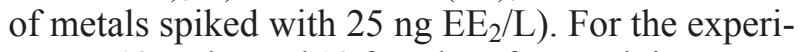
ments, 12 males and 12 females of mexcalpique were placed in each glass tank ( $7 \mathrm{~L}$ of test volume) using semi-hard synthetic water $\left(120 \mathrm{mg} / \mathrm{L}\right.$ as $\left.\mathrm{CaCO}_{3}\right)$ as dilutant in three independent experiments. Standard solutions of zinc sulphate, chloride iron, lead nitrate, manganese sulphate and copper sulphate dissolved in ultra-pure water at $10.0 \mathrm{~g} / \mathrm{L}$ were prepared just before the beginning of the experiments. Working solutions of metals were prepared and stored at 4 ${ }^{\circ} \mathrm{C}$ using semi-hard synthetic water as dilutant. On the other hand, standard solution of $\mathrm{EE}_{2}$ at $1.0 \mathrm{mg} /$ $\mathrm{mL}$ dissolved in ethanol HPLC (Sigma-Aldrich TM) was done, dissolution was performed to reach 1.0 $\mathrm{mg} / \mathrm{L}$. Total ethanol content by tank was $25 \mu \mathrm{L} / \mathrm{L}$ in fish exposed to T2. During the exposure, controls and treated fishes were not fed and were maintained by constant aeration and temperature $\left(23 \pm 2{ }^{\circ} \mathrm{C}\right)$, to a natural light cycle. Fishes were not fed because undigested food, dregs and detritus can modify the concentration and bioavailability of $\mathrm{EE}_{2}$ and metals in the water. Each day for seven days, four males and four females were euthanized by rapid freezing (15 $\mathrm{min} /-80^{\circ} \mathrm{C}$ ) according to the Mexican protocol for the production, protection and welfare of experimental animals (SAGARPA 2001) and necropsy was done. A total change of water was done after each sampling, and sufficient amount of standard solutions of metals and $\mathrm{EE}_{2}$ was added until the nominal concentrations of the test were reached. Control fish (12 males and 12 females) were maintained under the same conditions, without $\mathrm{EE}_{2}$, and metals and were sacrificed at days 7,14 and 21 .

\section{Physicochemical analysis}

Water samples $(1 \mathrm{~L})$ were collected every week (7, 14 and 21 days) just after the euthanization of fishes and the replacement of totality of water for chemical analysis. Physicochemical parameters, including conductivity, total dissolved solids, salinity, dissolved oxygen saturation, $\mathrm{pH}$, and redox potential were evaluated each day using a YSI Mod 556 MPS multiparametric probe. Concentrations of metals $(\mathrm{Cu}$, $\mathrm{Fe}, \mathrm{Mn}, \mathrm{Pb}$ and $\mathrm{Zn}$ ) were evaluated by acid digestion followed by flame atomic absorption spectrometry using the direct air-acetylene flame method 7000B published by Environmental Protection Agency of The United States of America with a GBC 932 Plus spectrophotometer as in an earlier study (Vega-López et al. 2013). Quantification $\mathrm{EE}_{2}$ was performed according to Wang et al. (2006) with modifications using a Shimadzu HPLC system coupled to a UV detector (Olivares-Rubio et al. 2015).

\section{Biomarkers}

Necropsy was done immediately after sacrifice to obtain the head under stereoscopic microscope and avoiding the inclusion of opercula, gills, eyes and jaws. Also, the liver and the gonads were obtained. Tissues were weighed to within $0.1 \mathrm{mg}$ and homogenized in $500 \mu \mathrm{L}$ with phosphate buffer solution (1X PBS) using Teflon micropestles. The homogenates were centrifuged at $4980 \mathrm{X} \mathrm{g}(9000 \mathrm{rpm})$ and $4{ }^{\circ} \mathrm{C}$ for $15 \mathrm{~min}$ in a Hermle Labnet Z216MK centrifuge to obtain the cytosolic fraction and stored at $-70^{\circ} \mathrm{C}$ until the biomarker assay (less than one week).

\section{Gonadotropins and estradiol}

Measuring of gonadotropins I and II (GtH I and $\mathrm{GtH}$ II) and estradiol $\left(\mathrm{E}_{2}\right)$ in the head and gonads was performed using specific ELISA kits for fish from CUSABIO TM Hubei Province 430206, P.R. China. 
The ELISA kits employed were Fish Follicle-Stimulating Hormone ELISA Kit (CSB-E15790Fh), Fish Luteinizing Hormone ELISA Kit (CSB-E15791Fh) and Fish Estradiol ELISA kit (CSB-E1301Fh). CUSABIO ${ }^{\mathrm{TM}}$ guaranteed specificity for fish species GtH I, GtH II and $\mathrm{E}_{2}$ and declares no significant cross-reactivity and interferences. No reactivity analysis with GtH I, GtH II and $\mathrm{E}_{2}$ specific of $G$. viviparus were done since manufacturer statement and because specific standards for this species do not exist. In addition, no procedures of purification for these gonadotropins and $\mathrm{E}_{2}$ were employed since the CUSABIO TM ensures that this quantification (GtH I and GtH II) could be done directly in serum and plasma of fish species. However, the small size of this fish species is a real impediment to obtain the blood in enough quantities for these assessments. As a consequence, the centrifuged head homogenate was employed for gonadotropins evaluation. In the case of $E_{2}$ measurement, it could be performed in tissue homogenates. According to CUSABIO TM ELISA Kits, method detection limits for GtH I was less to $0.4 \mathrm{mIU} / \mathrm{mL}$, less to $2.5 \mathrm{mIU} / \mathrm{mL}$ in the case of GtH II, and $25 \mathrm{pg} / \mathrm{mL}$ for $\mathrm{E}_{2}$. The intra and inter assay variance for $\mathrm{GtH}$ I, GtH II and $\mathrm{E}_{2}$ were lower than $8 \%$ expressed as variance coefficient (\% CV). The results were shown as International Units (IU) of GtH I and GtH II /g tissue (wet wt), meanwhile, the estradiol concentration was presented as $\mathrm{ng} / \mathrm{g}$ tissue.

\section{Vitellogenin and metallothionein}

The content of vitellogenin (VTG) was determined in the liver because in this tissue their synthesis occurs and in the gonads because in females they are the immediate target organs, meanwhile in males does not have target organ (Vega-López et al. 2007). However, VTG evaluation in the testis was performed. The quantification was made by enzyme-linked immunosorbent assay (ELISA) in an inhibition format using rabbit polyclonal antiVTG serum as described earlier (Vega-López et al. 2006). The method detection limit (MDL) of hybrid ELISA was calculated to be $0.005 \mathrm{ng}$ of G. viviparus VTG. MT induction and purification was performed by the method of Pedersen et al. (1994) with some modifications. Specimens of G. viviparus (10 males and 10 females) were exposed to $0.1 \mathrm{ppm}$ of $\mathrm{CdCl}_{2}$ (JT Baker ${ }^{\circledR}$ ) for 25 days. The MT fraction of the livers was concentrated on an Amicon 202 ultrafiltration system of molecular mass cut-off $5 \mathrm{kDa}$. The purified protein was used to obtain polyclonal antibodies in New Zealand rabbits in accordance with earlier reports (Vega-López et al. 2006). MT was measured in the liver, in the head and in the gonads of the mexcalpique, and quantification was performed with six replicates in three independent experiments by ELISA in an inhibition format using rabbit polyclonal anti-MT serum diluted at 1:7000. The MDL was of $0.012 \mathrm{ng}$ of G. viviparus MT. Both, VTG and MT content were expressed as ng/g tissue (wet wt) or $\mathrm{pg} / \mathrm{g}$ tissue as convenient. Total protein content was determined according to Bradford (1976) using bovine serum albumin (Merck) as a standard.

\section{Statistical analysis and Integrated Biomarker Response Index version 2}

With the aim to find statistical significant differences of the biomarker responses measured in G. viviparus with regards to control fish and among sexes at the same treatment, we used a one-way ANOVA with Bonferroni's post-test using GraphPad Prism version 5.00 for Windows, GraphPad Software, San Diego California USA. Correlations between biomarkers were estimated using the Pearson's correlation coefficient as linear correlation was performed using SPSS v.12.0 software. Integrated Biomarker Response version 2 (IBRv2) developed by Sanchez et al. (2012) to evaluate the integrated biological response by effects of treatments, exposure time and sex was used. This index assesses the deviation between biomarkers of specimens collected from a polluted, stressed site or exposed under controlled conditions compared to those from a reference site, unexposed, less polluted or not stressed animals.

\section{RESULTS}

\section{Physicochemical analysis}

Physicochemical variables evaluated with multiparametric probe were stable during both experiments (and its replicate) showed the following mean \pm standard deviation values: conductivity, $2.25 \pm$ $0.035 \mathrm{mS} / \mathrm{cm}$; total dissolved solids, $1615.6 \pm 25.86$ $\mathrm{mg} / \mathrm{L}$; salinity, $1.264 \pm 0.022 \mathrm{ppt}$; dissolved oxygen saturation presented in Mexico City (68-75\%) within $6.85 \pm 0.0512 \mathrm{mg} \mathrm{O}_{2} / \mathrm{L} ; \mathrm{pH}, 8.72 \pm 0.056$ and redox potential, $-52.63 \pm 8.39$. Metals and $\mathrm{EE}_{2}$ concentrations in water samples was lower than the nominal concentration (Table I).

\section{Biomarkers \\ Gonadotropins and estradiol}

The content of GtH I in the head and gonads in the mexcalpique exposed to $\mathrm{T} 1$ and $\mathrm{T} 2$ was greater than in control fish, particularly in the head of males $(\mathrm{p}<0.05$; 
TABLE I. CHEMICAL ANALYSIS OF WATER SAMPLES OBTAINED FROM THE TWO TREATMENTS BY DUPLICATED

\begin{tabular}{|c|c|c|c|}
\hline & \multicolumn{3}{|c|}{ Control } \\
\hline $\mathrm{Cu}(\mathrm{mg} / \mathrm{L})$ & \multicolumn{3}{|c|}{$0.098 \pm 0.042$} \\
\hline $\mathrm{Fe}(\mathrm{mg} / \mathrm{L})$ & \multicolumn{3}{|c|}{$0.062 \pm 0.022$} \\
\hline $\mathrm{Mn}(\mathrm{mg} / \mathrm{L})$ & \multicolumn{3}{|c|}{$0.041 \pm 0.029$} \\
\hline $\mathrm{Pb}(\mathrm{mg} / \mathrm{L})$ & \multicolumn{3}{|c|}{ ND } \\
\hline $\mathrm{Zn}(\mathrm{mg} / \mathrm{L})$ & \multicolumn{3}{|c|}{$0.106 \pm 0.073$} \\
\hline $\mathrm{EE}_{2}(\mathrm{ng} / \mathrm{L})$ & \multicolumn{3}{|c|}{ ND } \\
\hline & \multicolumn{3}{|c|}{$\mathrm{T} 1$} \\
\hline & 7 days & 14 days & 21 days \\
\hline $\mathrm{Cu}(\mathrm{mg} / \mathrm{L})$ & $0.308 \pm 0.102$ & $0.239 \pm 0.069$ & $0.236 \pm 0.098$ \\
\hline $\mathrm{Fe}(\mathrm{mg} / \mathrm{L})$ & $0.725 \pm 0.122$ & $0.684 \pm 0.186$ & $0.689 \pm 0.206$ \\
\hline $\operatorname{Mn}(\mathrm{mg} / \mathrm{L})$ & $0.029 \pm 0.013$ & $0.037 \pm 0.026$ & $0.067 \pm 0.041$ \\
\hline $\mathrm{Pb}(\mathrm{mg} / \mathrm{L})$ & $0.103 \pm 0.041$ & $0.099 \pm 0.058$ & $0.078 \pm 0.049$ \\
\hline $\mathrm{Zn}(\mathrm{mg} / \mathrm{L})$ & $0.097 \pm 0.022$ & $0.021 \pm 0.015$ & $0.026 \pm 0.016$ \\
\hline \multirow[t]{3}{*}{$\mathrm{EE}_{2}(\mathrm{ng} / \mathrm{L})$} & ND & ND & ND \\
\hline & \multicolumn{3}{|c|}{$\mathrm{T} 2$} \\
\hline & 7 days & 14 days & 21 days \\
\hline $\mathrm{Cu}(\mathrm{mg} / \mathrm{L})$ & $0.207 \pm 0.058$ & $0.189 \pm 0.075$ & $0.250 \pm 0.105$ \\
\hline $\mathrm{Fe}(\mathrm{mg} / \mathrm{L})$ & $0.793 \pm 0.233$ & $0.788 \pm 0.216$ & $0.803 \pm 0.103$ \\
\hline $\operatorname{Mn}(\mathrm{mg} / \mathrm{L})$ & $0.103 \pm 0.07$ & $0.178 \pm 0.08$ & $0.109 \pm 0.06$ \\
\hline $\mathrm{Pb}(\mathrm{mg} / \mathrm{L})$ & $0.086 \pm 0.075$ & $0.091 \pm 0.064$ & $0.076 \pm 0.062$ \\
\hline $\mathrm{Zn}(\mathrm{mg} / \mathrm{L})$ & $0.024 \pm 0.017$ & $0.023 \pm 0.019$ & $0.024 \pm 0.025$ \\
\hline $\mathrm{EE}_{2}(\mathrm{ng} / \mathrm{L})$ & $12.25 \pm 5.98$ & $13.32 \pm 6.41$ & $14.65 \pm 7.54$ \\
\hline
\end{tabular}

Mean \pm standard deviation, $\mathrm{ND}=$ no detected. $\mathrm{T} 1=$ treatment 1 , mixture of metals at environmentally relevant concentrations $(\mathrm{Cu}=0.4 \mathrm{mg} / \mathrm{L}, \mathrm{Fe}=0.9 \mathrm{mg} / \mathrm{L}, \mathrm{Mn}$ $=0.3 \mathrm{mg} / \mathrm{L}, \mathrm{Pb}=0.13 \mathrm{mg} / \mathrm{L}$ and $\mathrm{Zn}=0.15 \mathrm{mg} / \mathrm{L}) . \mathrm{T} 2=$ treatment 2 , the same mixture of metals spiked with $25 \mathrm{ng} \mathrm{EE} / \mathrm{L}$

Fig. 1A and B). The amount of this hormone was higher in male fishes than in female fishes. By exposure to metals (T1), GtH I in males presented an inverse timedependent response in both head and gonads (Fig. 1A and 1B). The effect of metals in addition to $\mathrm{EE}_{2}$ (T2) about GtH I content induced an irregular response in the time in the males and females (Fig. 1A and B). In contrast, GtH II in both tissues (head and gonads) was lower than in the control group. In the head of males exposed to T1, GtH II levels were inversely related to the exposure time ( $p<0.05$; Fig. 1C); meanwhile, in the fish exposed to $\mathrm{T} 2$, a noticeable diminution in GtH II was found (Fig. 1D). In the gonads of males and females, an inverse time-dependent response about $\mathrm{GtH}$ II levels was detected, undetectable at the end of the exposure ( $p<0.001$; Fig. 1D).

On the other hand, the content of estradiol showed differences between sexes and tissues. In the head of male $G$. viviparus treated with $\mathrm{T} 1$ and $\mathrm{T} 2$, concentration of $\mathrm{E}_{2}$ increased almost in a time-dependent manner, particularly in those exposed to $\mathrm{T} 2$ that showed significant differences regarding to controls $(\mathrm{p}<0.05$ and 0.01$)$ (Fig. $\mathbf{2 A}$ and $\mathbf{2 B}$ ). In contrast, in the head of female fishes exposed to $T 1$, a peak of $E_{2}$ was detected at day 14 , posterior a decline occurs. In the gonads of females exposed to $\mathrm{T} 1$ and $\mathrm{T} 2$, a decay of $\mathrm{E}_{2}$ levels was noted particularly at day $7(p<0.05)$. However, a slight recovery of $E_{2}$ levels at day 14 and 21 was detected; but in no case the basal level was reached.

\section{Vitellogenin and metallothionein}

In general, metals did not stimulate the VTG content, neither in the liver nor in gonads of the mexcalpique with regard to control group. In contrast, the effect of T2, VTG concentration in liver and gonads of male fishes were higher than in the control group ( $\mathrm{p}<0.05$ and 0.01 ; Fig. 2C and 2D). However, this induction was not sustained over the time as observed also in the liver of female fish 

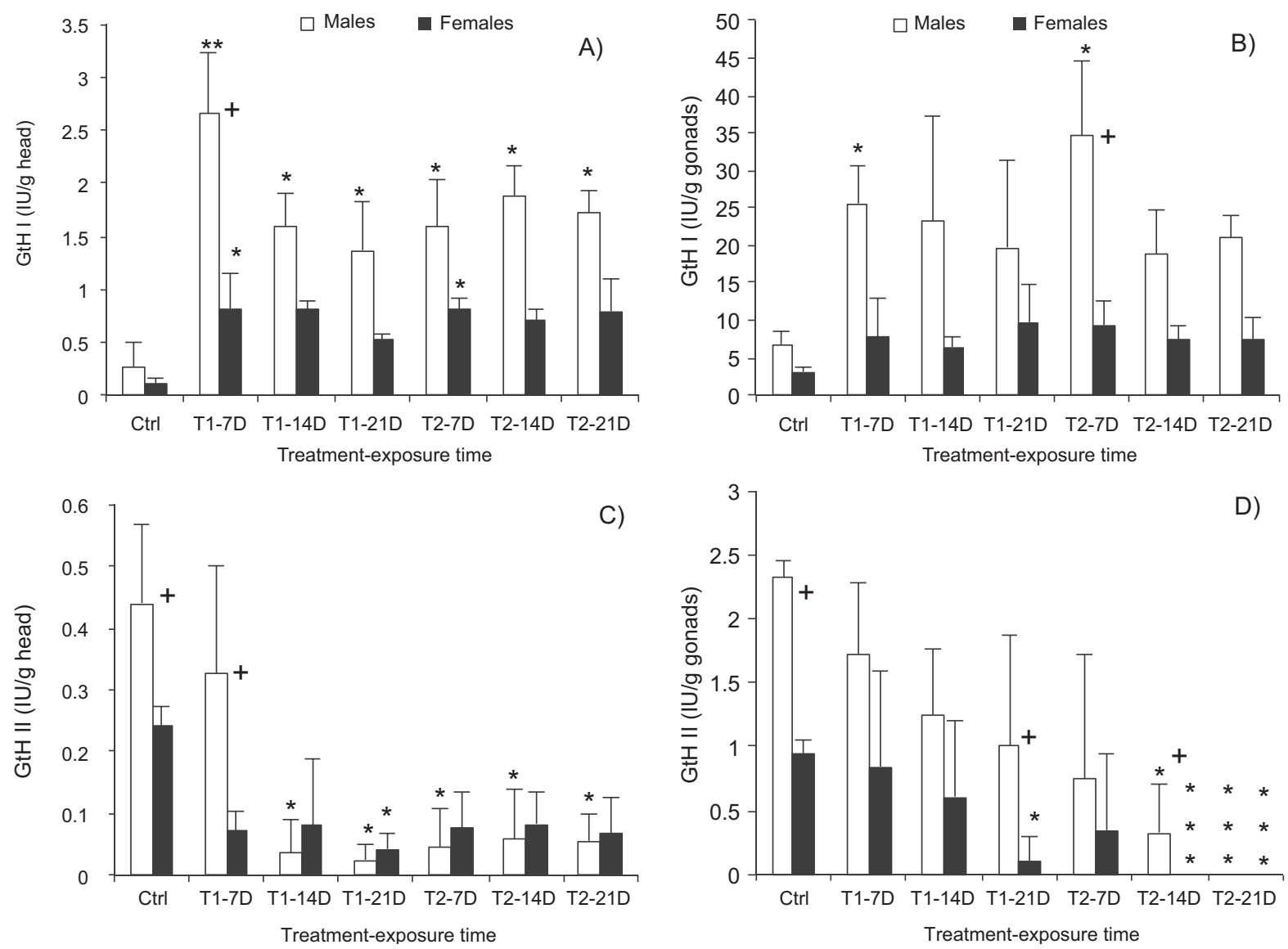

Fig. 1. Content of gonadotropins I (GtH I) and II (GtH II) in the head and gonads of Girardinichthys viviparus exposed under controlled conditions to mixture of metals (T1) and mixture of metals spiked with $25 \mathrm{ng} / \mathrm{L}$ of ethynil estradiol (T2). $7 \mathrm{D}=7$ days, $14 \mathrm{D}=14$ days and $21 \mathrm{D}=21$ days. A) content of $\mathrm{GtH} \mathrm{I}$ in the head, B) content of $\mathrm{GtH}$ I in gonads, C) content of GtH II in head and D) content GtH II in gonads. Bars represent the mean and standard deviation of data set. Asterisks denote significance difference regarding to their corresponding control group ( $\operatorname{sex})^{*} \mathrm{p}<0.05,{ }^{* *} \mathrm{p}<0.01$ and $* * *$ $\mathrm{p}<0.001 ;+$ denote significance difference at $\mathrm{p}<0.05$ between sexes in the same treatment

(Fig. 2C). Meanwhile, in the gonads of female fish exposed to T2, VTG induction in a time-dependent manner was observed (Fig. 2D).

The concentration of MT was higher in males than in females in the tissues under study in control fish as in fish exposed with the exception of hepatic MT female controls. In the head of fish of both sexes exposed to T1 and T2 induction of MT, an inverse timedependent manner was detected (Fig. 3A). However, in the liver and in the gonads in fish exposed to T1, an induction of MT with a peak at 14 days was found mainly in male fish $(\mathrm{p}<0.01)$, but MT levels were not sustained at 21 days. In fishes exposed to T2, initial induction of MT prevails particularly in male fish than in female fish (Fig. 3B and 3C).

In the G. viviparus exposed with T1, a number of relations between biomarkers were found, particularly in male fish. In contrast, in fish exposed to T2, the relations were lower than in fish exposed to $\mathrm{T} 1$ (Table II).

\section{Integrated Biomarker Response Index version 2 (IBRv2)}

In an interesting way, the greater values of IBRv2 were found at 14 days in male and female fish exposed to both treatments (T1 and T2), except for female fish treated with T2 where the greater IBRv2 was found at 7 days (Table III). The star plot area values showed a sex-linked response. In male fish exposed to T1, an induction of MT in the head, liver and gonads and elevation of GtH I and $\mathrm{E}_{2}$ in the head was noted with regard to T2; in contrast, in male fish treated with T2, an increase of VTG in the liver was found (Fig. 4). Compared with male fish, in female fish, the integration of the response was lower in specimens treated with both treatments (Fig. 5). 

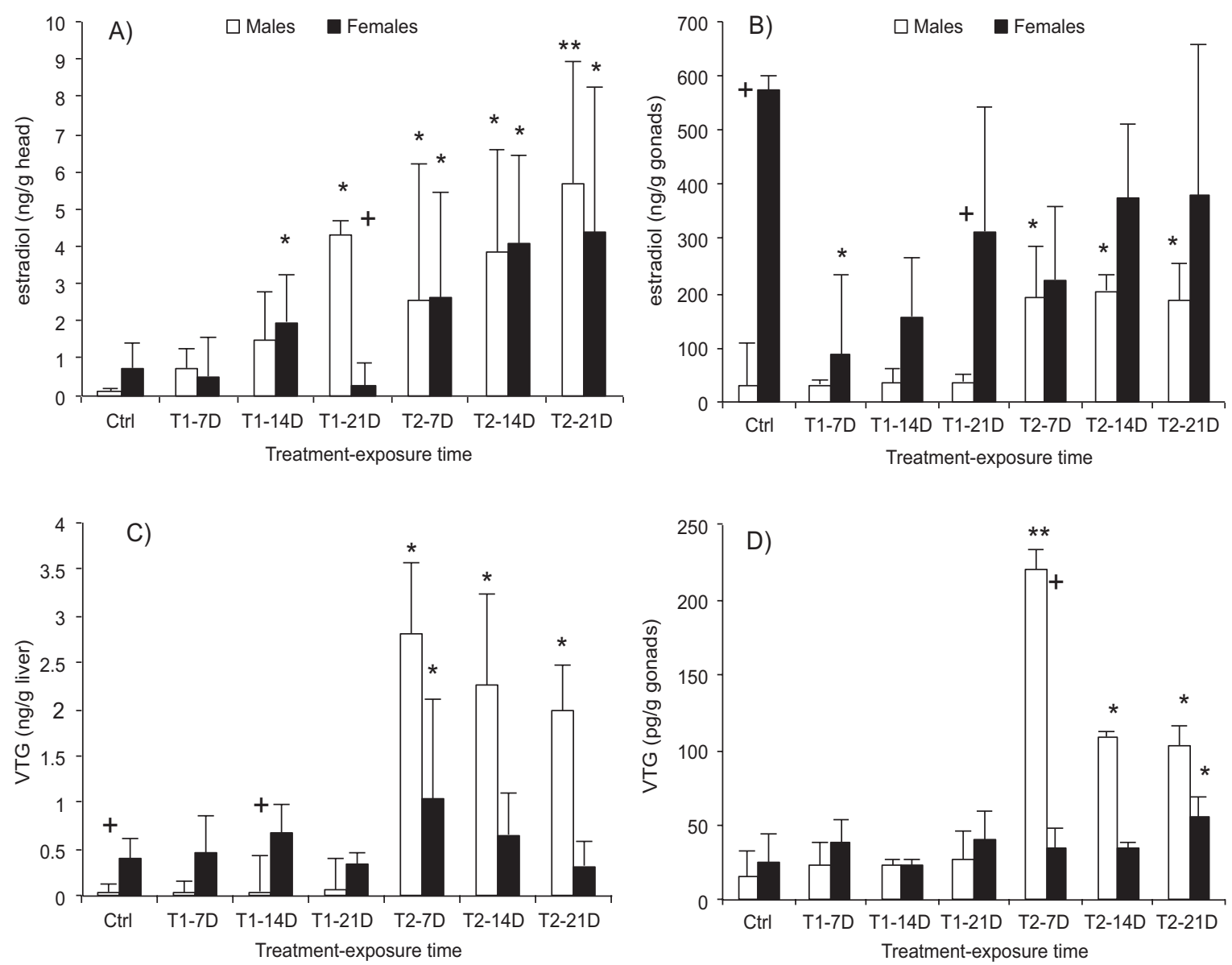

Fig. 2. Content of estradiol $\left(\mathrm{E}_{2}\right)$ in the head and gonads and vitellogenin (VTG) in the liver and gonads of Girardinichthys viviparus exposed under controlled conditions to mixture of metals (T1) and mixture of metals spiked with $25 \mathrm{ng} / \mathrm{L}$ of ethynil estradiol (T2). 7D $=7$ days, $14 \mathrm{D}=14$ days and $21 \mathrm{D}=21$ days. A) content of $\mathrm{E}_{2}$ in the head, B) content of $\mathrm{E}_{2}$ in the gonads, C) content of VTG in the liver, D) content of VTG in the gonads. Bars represent the mean and standard deviation of data set. Asterisks denote significance difference regarding to their corresponding control group $(\operatorname{sex}) * \mathrm{p}<0.05, * * \mathrm{p}<0.01$ and $* * * \mathrm{p}<0.001 ;+$ denote significance difference at $\mathrm{p}<0.05$ between sex in the same treatment

\section{DISCUSSION}

It was documented for the first time that mixture of metals induces changes in gonadotropins levels in the head and gonads of the mexcalpique. The GtH II in the head and gonads of G. viviparus were lower than in control group in both treatments (T1 and T2). It has been documented that some metals could potentially act on the male axis $\mathrm{GnRH}$ system impairing the GtH II secretion (Klein et al. 1994, Khan and Thomas 2000, Szczerbik et al. 2006) as in female fish (Crump and Trudeau 2009). Previous report and current results suggested that the lead present in the mixture of metals could disrupt the system GnRH-GtH II in the mexcalpique of both sexes. This effect possibly occurs because depletion of GtH II in the head as a decay in the gonads. However, it is not possible to distinguish the possible toxic effects of the other metals in or not in addition to estrogenic compounds on the disruption of GtH II release.

In an interesting way, the content of GtH I showed an induction in the head and gonads particularly in male fish exposed to T1 and T2. It was found by Pearson moment correlation analysis that the induction of MT in the head of male fish exposed to T1 (Fig. 3A) was related to GtH I in the gonads ( $p<$ 0.05 , Table II) suggesting that some metals in the mixture could enhance GtH I. In agreement with these results, in male $G$. viviparus inhabitant of a highly polluted lake, a positive relationship of zinc with VTG in vivo using multivariate approach was documented (Olivares-Rubio et al. 2015). Current results suggest that certain metals at threshold endogenous levels would modify the mRNA expression 

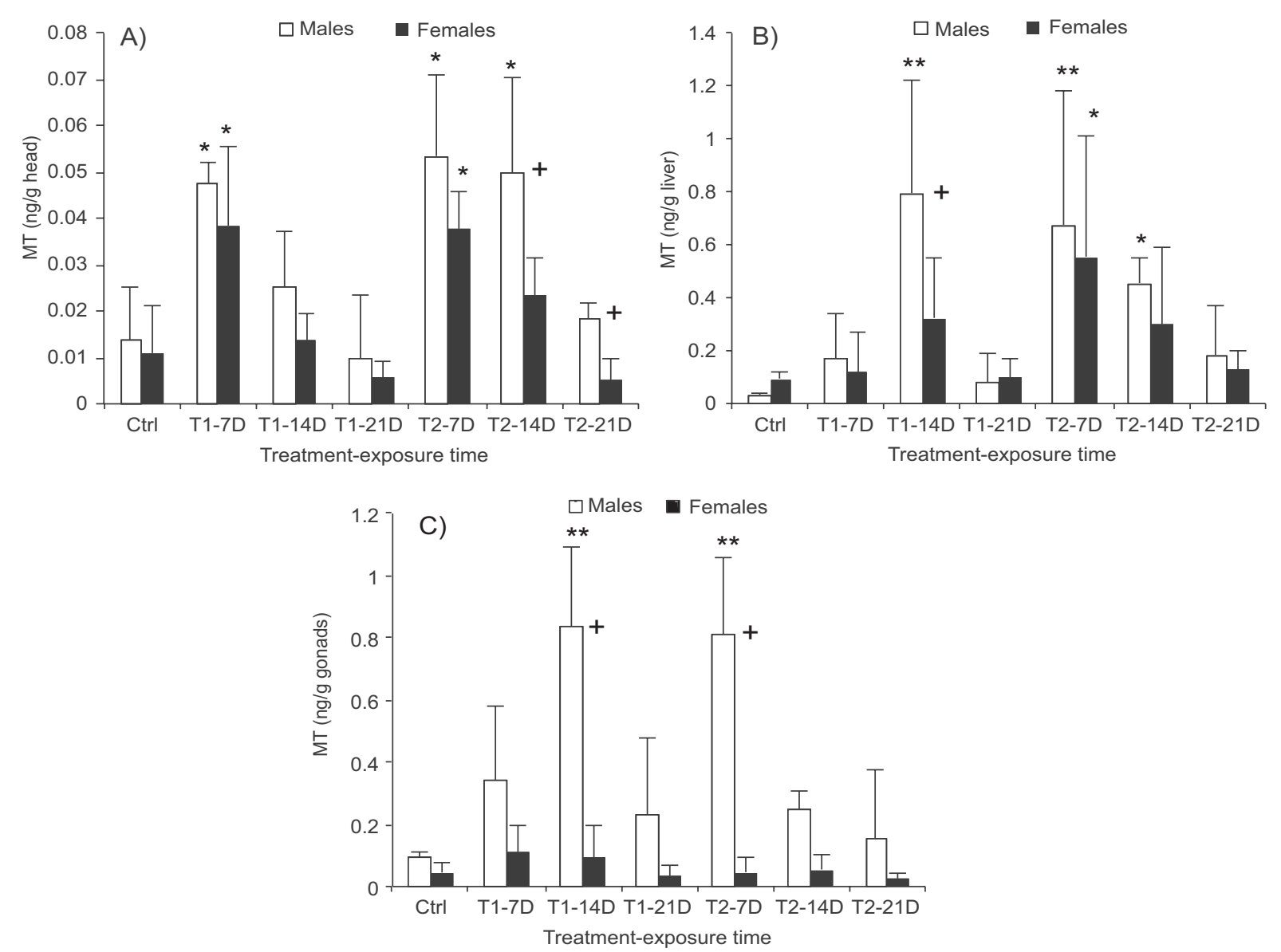

Fig. 3. Content of metallothioneins (MT) in the head, liver and gonads of Girardinichthys viviparus exposed under controlled conditions to mixture of metals (T1) and mixture of metals spiked with $25 \mathrm{ng} / \mathrm{L}$ of ethynil estradiol (T2). $7 \mathrm{D}=7 \mathrm{days}$, $14 \mathrm{D}=14$ days and $21 \mathrm{D}=21$ days. A) content of MT in the head, B) content of MT in the liver, and C) content of MT in gonads. Bars represent the mean and standard deviation of data set. Asterisks denote significance difference regarding to their corresponding control group (sex) $* \mathrm{p}<0.05, * * \mathrm{p}<0.01$ and $* * * \mathrm{p}<0.001 ;+$ denote significance difference at $\mathrm{p}<0.05$ between sexes in the same treatment

at DNA element response of GnRH-gonadotropins system. In addition, some metals could disrupt the GnRH-gonadotropins system by alteration of calcium homeostasis (Yuan et al. 2013). In the brain of rainbow trout (Oncorhynchus mykiss) exposed to Cd (5 and $10 \mu \mathrm{g} / \mathrm{L})$ mRNA levels of GnRH1and GnRH2 was greatly enhanced in a concentration-dependant manner; probably because $\mathrm{Cd}$ alters $\mathrm{E}_{2}$ signalling pathways and could affect the reproductive axis by non-estrogenic mechanisms (Vetillard and Bailhache 2005). However, if exogenous estrogens are present, the response elicited by metals could be modified. Vetillard and Bailhache (2005) showed that $\mathrm{E}_{2}$ treatments did not modify GnRH1and GnRH2 mRNA levels in the brain of rainbow trout. However, $\mathrm{Cd}$ in combination with $\mathrm{E}_{2}$ stimulated these mRNAs. In wild male $G$. viviparus, it was found that $\mathrm{Zn}$ and $\mathrm{Pb}$ could (up and down) regulate hypothalamus-pituitary axis (Olivares-Rubio et al. 2015). More studies are needed to clarify interactions of exogenous estrogens with metals at GnRH-gonadotropins system.

GtH II levels in the head and gonads of male fish exposed to T2 significantly decreased with regard to control fish, particularly in the gonads. However, levels of GtH I in the head of male and female fish exposed to T2 with a peak at days 14 and 7, respectively coincides with the greater values of IBRv2 for this treatment (Table III).

Different pattern of response was observed by Integrated Biomarker Response index version 2 (IBRv2) in fish exposed to T1. Gonadal GtH I of fish exposed to T2 showed a more pronounced response in male fish with regard to their own controls; additionally in both sexes a peak at day 7 was observed (females higher IBRv2). No apparent relation among MT in the head and GtH I in fish of both sexes 
TABLE II. SIGNIFICANT CORRELATIONS OF THE BIOMARKERS EVALUATED IN Girardinichthys viviparus EXPOSED TO T1 AND T2 USING PEARSON MOMENT CORRELATION

\begin{tabular}{llrl}
\hline Biomarker 1 & Biomarker 2 & \multicolumn{1}{c}{$\mathrm{r}^{2}$} & $p$ value \\
\hline \multicolumn{4}{c}{ Male exposed to T1 } \\
\hline GtH II G & E $_{2}$ G & -0.998 & 0.040 \\
GtH I G & MT H & 0.997 & 0.050 \\
E $_{2}$ H & VTG G & 0.998 & 0.046 \\
E $_{2}$ G & VTG L & 0.997 & 0.048 \\
E $_{2}$ G & MT H & -1.000 & 0.012 \\
VTG L & MT H & -0.998 & 0.036 \\
MT L & MT G & 0.998 & 0.039 \\
\hline \multicolumn{4}{c}{ Female exposed to T1 } \\
\hline GtH II G & E G & -1.000 & 0.000 \\
GtH II H & VTG G & 0.998 & 0.040 \\
E $_{2}$ H & VTG G & -1.000 & 0.003 \\
E $_{2}$ H & MT L & 0.999 & 0.028 \\
\hline & \multicolumn{4}{c}{ Male exposed to T2 } \\
\hline GtH I H & GtH II G & -0.999 & 0.024 \\
E $_{2}$ H & MT L & -0.999 & 0.028 \\
\hline & Female exposed to T2 \\
\hline GtH I H & GtH I G & 1.000 & 0.018 \\
GtH II H & E G & -0.999 & 0.026 \\
VTG L & MT L & 0.997 & 0.048 \\
\hline
\end{tabular}

$\mathrm{GtH}=$ gonadotropins, $\mathrm{E}_{2}=$ estradiol, $\mathrm{VTG}=$ vitellogenin, $\mathrm{MT}=$ metallothioneins, $\mathrm{H}=$ head, $\mathrm{L}=$ liver, $\mathrm{G}=$ gonads. $\mathrm{T} 1$ = treatment 1 , mixture of metals at environmentally relevant concentrations $(\mathrm{Cu}=0.4 \mathrm{mg} / \mathrm{L}, \mathrm{Fe}=0.9 \mathrm{mg} / \mathrm{L}, \mathrm{Mn}=0.3 \mathrm{mg} / \mathrm{L}, \mathrm{Pb}=0.13 \mathrm{mg} / \mathrm{L}$ and $\mathrm{Zn}=0.15 \mathrm{mg} / \mathrm{L}$ ). T2 $=$ treatment 2 , the same mixture of

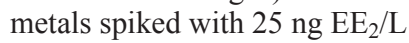

exposed to T2 was observed, suggesting a main role of $\mathrm{EE}_{2}$ in the disruption of GnRH-gonadotropin system (Fig. 4 and 5) despite toxic effects elicited by the mixture of metals previously detailed.

Two findings suggest a feedback mechanism of exogenous estrogens involved in the disruption of metals on the GnRH-gonadotropin system: i) The depletion of GtH II at the head of male fish exposed to T2 showed an inverse response with enhancement of GtH I in the testis ( $\mathrm{p}<0.05)$. ii) In female fish, the stimulation GtH I in the head and gonads presented a similar induction during the exposure time, and their levels were above that of the control fish $(p<0.05)$. The probable consequence of these toxic effects in male $G$. viviparus is the disruption of 11-keto testosterone production by an imbalance in the activity of cyp 450 aromatase (Cheshenko et al. 2008) favouring the production of E2 mediated by gonadotropins. The induction of GtH I in the head and gonads and depletion of GtH II could also be hazardous to adult female mexcalpique because GtH II plays a main role in $E_{2}$ synthesis. Previous reports and current findings corroborate that this feedback mechanism is also regulated by exogenous estrogen. However, other interactions involved in up-regulation and down-regulation of release of gonadotropins are not discernable (Yaron et al. 2003, Aroua et al. 2012, Karigo et al. 2014).

In females, GtH I and GtH II induced the release of female steroid hormones as is the case of $E_{2}$ (Rempel and Schlenk 2008). Meanwhile in males stimulates testicular androgen secreted by Sertoli and Leydig cell proliferation (Swanson et al. 2003). The gonads of female fishes are the main source of $\mathrm{E}_{2}$. However, in the brain, the expression of aromatase (cyp19), which convert androgens to estrogens has been reported in teleost fish (Diotel et al. 2010). In this regard, it was documented that the estrogens can up-regulate aromatase activity leading an elevated serum $\mathrm{E}_{2}$ concentration in both, male and female fish (Filby et al. 2007). In male G. viviparus, it is possible that the same phenomena occur by exposure to metals and by $\mathrm{EE}_{2}$. In teleost fish, GtH I stimulated vitellogenesis through the production of $\mathrm{E}_{2}$ (Janz and Weber 2000). The potential consequence of induction of $\mathrm{E}_{2}$-mediated by metals exposure in male $G$. viviparus could favour their feminization. This suggestion could be supported through the high levels of $E_{2}$ in the head of male mexcalpique and high VTG levels in their liver were found $(\mathrm{p}<0.05)$. Similar feminization elicited by $E_{2}$ was documented in male C. auratus exposed in situ to exogenous estrogens, among other compounds (Yan et al. 2012).

However, in female fish, induction of $E_{2}$ in the head by exposure to $\mathrm{T} 1$ was not sustained during the exposure suggesting a feedback mechanism. This finding is possible since the basal level of $E_{2}$ was overcome and because there is a possible inverse relation between head $\mathrm{E}_{2}$ levels with ovarian VTG observed ( $\mathrm{p}$ $<0.001$ ). In contrast, a peak of $E_{2}$ was accompanied by noticeable decay of GtH II in a time-dependant manner in the head of male G. viviparus treated with $\mathrm{T} 1$. These responses suggest the main role of GtH I in the synthesis of $E_{2}$ because both biomarkers showed an inverse response in the male mexcalpique. Similar results were documented in the hypophysectomized walking catfish (Clarias batrachus) treated with semipurified GtH I and GtH II at the dose level of $5 \mu \mathrm{g} /$ fish/day for 7 days (Sarkar et al. 2014).

On the other hand, an inverse relationship of MT in head of male $G$. viviparus exposed to T1 with testis 
TABLE III. AREA VALUES OF INTEGRATED BIOLOGICAL RESPONSE VERSION 2 FOR THE BIOMARKERS IN THE TISSUES UNDER STUDY OF Girardinichthys viviparus EXPOSED TO T1 AND T2

\begin{tabular}{|c|c|c|c|c|c|c|c|c|c|c|c|c|}
\hline & \multicolumn{6}{|c|}{$\mathrm{T} 1$} & \multicolumn{6}{|c|}{$\mathrm{T} 2$} \\
\hline & \multicolumn{3}{|c|}{ Male } & \multicolumn{3}{|c|}{ Female } & \multicolumn{3}{|c|}{ Male } & \multicolumn{3}{|c|}{ Female } \\
\hline & $7 \mathrm{D}$ & $14 \mathrm{D}$ & $21 \mathrm{D}$ & $7 \mathrm{D}$ & $14 \mathrm{D}$ & $21 \mathrm{D}$ & $7 \mathrm{D}$ & $14 \mathrm{D}$ & $21 \mathrm{D}$ & $7 \mathrm{D}$ & $14 \mathrm{D}$ & $21 \mathrm{D}$ \\
\hline GtH I H & 2.146 & 1.617 & 1.453 & 2.578 & 2.556 & 2.153 & 0.617 & 0.738 & 0.675 & 2.130 & 2.006 & 2.109 \\
\hline GtH I G & -0.319 & -0.418 & -0.591 & 0.135 & -0.032 & 0.343 & -0.935 & -0.935 & -1.371 & 0.606 & -0.259 & -0.254 \\
\hline GtH II H & -0.835 & -3.118 & -3.525 & -0.676 & -0.545 & -1.135 & -0.894 & -1.199 & -1.405 & -0.836 & -0.750 & -0.945 \\
\hline GtH II G & -1.555 & -1.892 & -2.113 & -0.265 & -0.557 & -2.192 & -2.425 & -3.013 & -1.624 & -1.291 & -0.457 & -0.457 \\
\hline $\mathrm{E}_{2} \mathrm{H}$ & 1.907 & 2.634 & 3.735 & -0.379 & 0.821 & -0.928 & 0.969 & 0.969 & 0.969 & 0.694 & 1.056 & 1.108 \\
\hline$E_{2} G$ & -2.212 & -2.118 & -2.062 & -4.657 & -4.109 & -3.486 & -1.377 & -1.321 & -1.383 & -4.018 & -3.597 & -3.581 \\
\hline VTG L & 0.079 & 0.547 & 0.822 & 0.326 & 0.692 & 0.074 & 3.008 & 2.849 & 2.757 & 0.714 & 0.335 & -0.249 \\
\hline VTG G & -1.626 & -1.596 & -1.440 & -1.211 & -1.665 & -1.156 & -0.520 & -1.022 & -1.063 & -1.620 & -1.612 & -1.227 \\
\hline MT H & 2.304 & 1.629 & 0.628 & 2.913 & 1.973 & 1.159 & 1.584 & 1.535 & 0.810 & 2.507 & 2.116 & 2.116 \\
\hline MT L & 2.294 & 3.929 & 1.514 & 1.048 & 1.958 & 0.864 & 2.364 & 2.082 & 1.435 & 2.022 & 1.504 & 0.782 \\
\hline MT G & 1.544 & 2.488 & 1.123 & 1.979 & 1.7936 & 0.804 & 1.335 & 0.492 & 0.1552 & 0.883 & 1.027 & 0.371 \\
\hline IBRv2 & 16.821 & 21.986 & 19.008 & 16.167 & 16.703 & 14.294 & 16.027 & 16.159 & 13.649 & 17.321 & 14.719 & 13.200 \\
\hline
\end{tabular}

$\mathrm{GtH}$ II = gonadotropin I, GtH II = gonadotropin II, $\mathrm{E}_{2}=$ estradiol, $\mathrm{VTG}=$ vitellogenin, $\mathrm{MT}=$ metallothioneins, $\mathrm{H}=\mathrm{head}, \mathrm{L}=$ liver, $\mathrm{G}=$ gonads, $\mathrm{D}=$ days after exposure. $\mathrm{T} 1=$ treatment 1 , mixture of metals at environmentally relevant concentrations $(\mathrm{Cu}=0.4 \mathrm{mg} / \mathrm{L}$, $\mathrm{Fe}=0.9 \mathrm{mg} / \mathrm{L}, \mathrm{Mn}=0.3 \mathrm{mg} / \mathrm{L}, \mathrm{Pb}=0.13 \mathrm{mg} / \mathrm{L}$ and $\mathrm{Zn}=0.15 \mathrm{mg} / \mathrm{L}$ ). T2 = treatment 2, the same mixture of metals spiked with $25 \mathrm{ng} \mathrm{EE}_{2} / \mathrm{L} . \mathrm{EE}_{2}=17 \alpha$-ethynil estradiol

$\mathrm{E}_{2}$ levels was found. In female mexcalpique, a similar response between hepatic MT with $\mathrm{E}_{2}$ in the head was observed $(p<0.05)$. Probably, the binding of metals in the head of male fish and in the liver of female fish allows the deregulation of the GnRH-gonadotropins system. Homeostatic regulation of metals are in part by MT which permits their transportation to specific cellular compartments where its function is required or altering its toxicity (Sears 2013).

$\mathrm{EE}_{2}$ could increase the toxic effects of metals in G. viviparus. The estrogenic effects elicited by xeno-estrogens by binding to ER is well documented (Sumpter and Jobling 1995, Shanle and Xu 2011). However, the mechanism of $\mathrm{EE}_{2}$ in addition to metals on the disruption of HPLG axis is not clear. In this regard, increases of $\mathrm{P} 450$ aromB transcript abundance have been reported in zebrafish (Danio rerio) juveniles exposed to $\mathrm{EE}_{2}$ (Kazeto et al. 2004, Vosges et al. 2010) besides in the head of roach (Rutilus rutilus) at 28 and 56 days after spawning (Lange et al. 2008). These findings indicate that metals and $\mathrm{EE}_{2}$ could disrupt the HPLG axis by non specific mechanism. Increases in the level of $\mathrm{E}_{2}$ were more evident in mexcalpique exposed to $\mathrm{T} 2$ than in T1. Additionally, an inverse response between hepatic MT with $\mathrm{E}_{2}$ in the head of male mexcalpique exposed to T2 was detected ( $p<$ $0.05)$, suggesting a negative regulation of hepatic MT on the disruption of GnRH-gonadotropins system. However, only in the gonads of female
G. viviparus exposed to $\mathrm{T} 2$, the content of $\mathrm{E}_{2}$ was lower than in their own controls. This particular finding could be explained probably by early increase of VTG synthesis in the liver and by late increases of VTG in the gonads. Although, $\mathrm{EE}_{2}$ is likely responsible for this protein induction, it is not possible to rule out that endogenous $E_{2}$ could participate in VTG synthesis since this steroid is the natural agonist of ER (Sumpter and Jobling 1995).

No significant changes in VTG content were observed in the liver and gonads of male and female G. viviparus exposed T1. However, the increase of MT in the head was apparently related to the lack of induction of VTG in male fish $(p<0.05)$. Current results indicate that disruption of HPLG axis by exposure of metals occurs at hypothalamus-pituitary control point.

In contrast, in the liver of fish exposed T2, levels of VTG showed an early induction, particularly in male mexcalpique explained by the high estrogenic effects elicited by $\mathrm{EE}_{2}$ via ER in fishes. The opposite, in female mexcalpique, a late capture of VTG in the gonads matched with $\mathrm{E}_{2}$ content in the ovary and with total depletion of GtH II was detected. These findings suggest that $\mathrm{EE}_{2}$ in presence of metals elicited a sex-linked response. In male fish, it is probable that the deregulating of the function of Sertoli cell allows an up-regulating of aromatase activity leading a female hormonal profile (Yan et al. 
$\mathrm{T} 1$

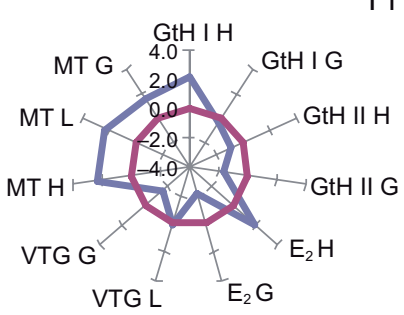

7D

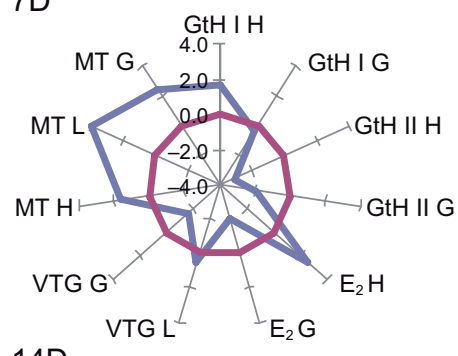

$14 \mathrm{D}$

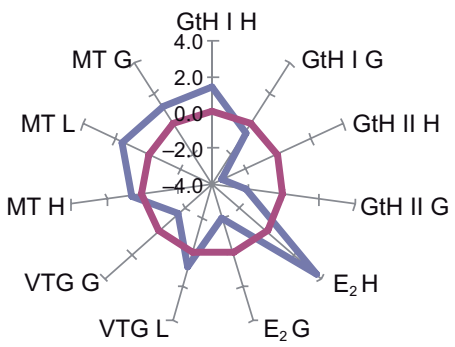

21D

Fig. 4. Star plot areas obtained by the method of Integrated Biological Response version 2 for the biomarkers evaluated in male Girardinichthys viviparus exposed to $\mathrm{T} 1(\mathrm{Cu}=0.4 \mathrm{mg} / \mathrm{L}, \mathrm{Fe}=0.9 \mathrm{mg} / \mathrm{L}$, $\mathrm{Mn}=0.3 \mathrm{mg} / \mathrm{L}, \mathrm{Pb}=0.13 \mathrm{mg} / \mathrm{L}$ and $\mathrm{Zn}=0.15 \mathrm{mg} / \mathrm{L})$ and $\mathrm{T} 2(\mathrm{Cu}$ $=0.4 \mathrm{mg} / \mathrm{L}, \mathrm{Fe}=0.9 \mathrm{mg} / \mathrm{L}, \mathrm{Mn}=0.3 \mathrm{mg} / \mathrm{L}, \mathrm{Pb}=0.13 \mathrm{mg} / \mathrm{L}$ and

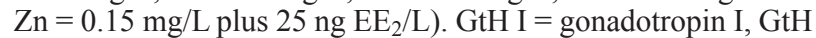
$\mathrm{II}=$ gonadotropin II, $\mathrm{E}_{2}=$ estradiol, $\mathrm{VTG}=$ vitellogenin, $\mathrm{MT}=$ metallothioneins, $\mathrm{H}=$ head, $\mathrm{L}=$ liver, $\mathrm{G}=$ gonads. $\mathrm{D}=$ days after exposure. The blue line represents the deviation with regard to basal values (red line)

2012). Meanwhile, in female mexcalpique, metals and $\mathrm{EE}_{2}$ induce an imbalance between both gonadotropins involved in regulation of HPLG axis that in the current study favouring a late vitellogenesis mediated by $\mathrm{EE}_{2}$.

Early induction of MT in the liver coincided with early induction of VTG. Thompson et al. (2003) has reported that changes in zinc concentration in the bloodstream of female squirrelfish (Holocentrus adscensionis) followed the same time course as VTG transport from the liver. In addition, hepato-ovarian translocation of zinc suggests that VTG might be a vehicle for this metal (Thompson et al. 2012). Current results and preceding studies
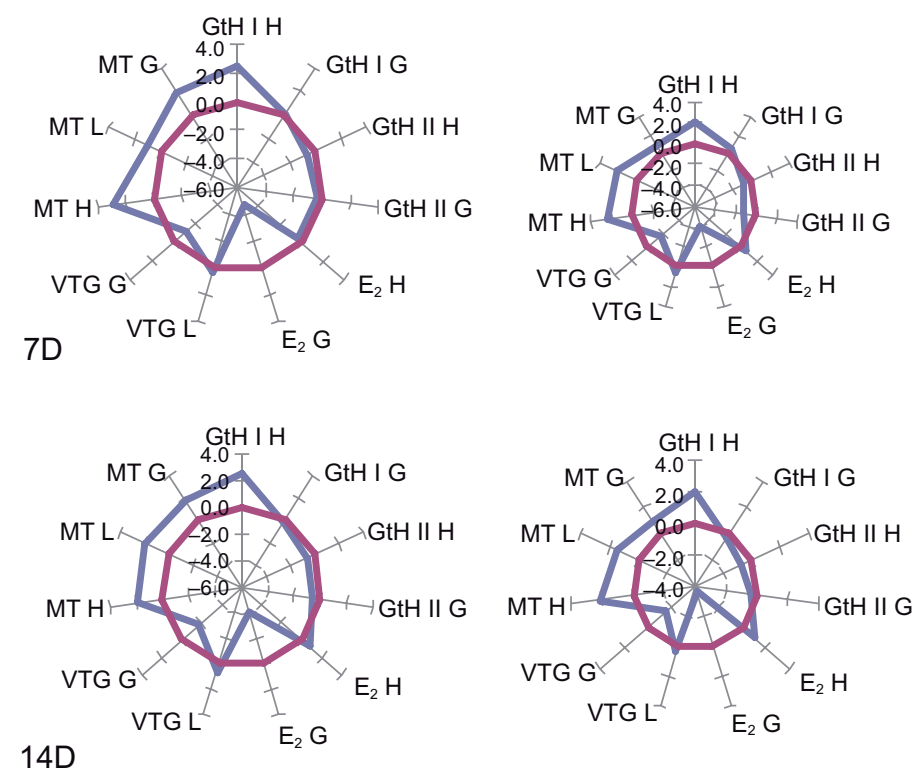

$14 \mathrm{D}$
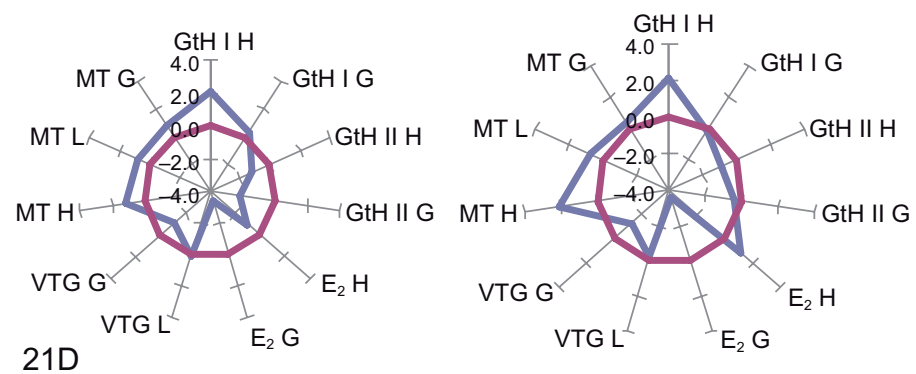

Fig. 5. Star plot areas obtained by the method of Integrated Biological Response version 2 for the biomarkers evaluated in female $G$. viviparus exposed to $\mathrm{T} 1(\mathrm{Cu}=0.4 \mathrm{mg} / \mathrm{L}, \mathrm{Fe}=0.9 \mathrm{mg} / \mathrm{L}, \mathrm{Mn}=0.3 \mathrm{mg} / \mathrm{L}$, $\mathrm{Pb}=0.13 \mathrm{mg} / \mathrm{LandZn}=0.15 \mathrm{mg} / \mathrm{L})$ and $2(\mathrm{Cu}=0.4 \mathrm{mg} / \mathrm{L}, \mathrm{Fe}=0.9 \mathrm{mg} / \mathrm{L}$, $\mathrm{Mn}=0.3 \mathrm{mg} / \mathrm{L}, \mathrm{Pb}=0.13 \mathrm{mg} / \mathrm{L}$ and $\mathrm{Zn}=0.15 \mathrm{mg} / \mathrm{L}$ plus $25 \mathrm{ng} \mathrm{EE}_{2} / \mathrm{L}$ ). $\mathrm{GtH} \mathrm{I}=$ gonadotropin I, GtH II = gonadotropin II, E 2 = estradiol, $\mathrm{VTG}=$ vitellogenin, $\mathrm{MT}=$ metallothioneins, $\mathrm{H}=$ head, $\mathrm{L}=$ liver, $\mathrm{G}=$ gonads. $\mathrm{D}=$ days after exposure. The blue line represents the deviation with regard to basal values (red line)

indicate that $\mathrm{Zn}$ chelated by MT is closely related to VTG induction.

\section{CONCLUSION}

The endocrine disruption of the sexual control axis in fish with matrotrophy viviparity showed clear differences in between sexes in G. viviparus exposed to a mixture of metals and metals spiked with $\mathrm{EE}_{2}$. The main disruption of the HPLG axis elicited by both, metals and spiked with $\mathrm{EE}_{2}$ occurs at hypothalamic-pituitary control point affecting basically the gonads function. By exposure to these toxicants, the male fish was the most damaged; however, female 
fish could counterpart this damage apparently by feedback mechanism mediated by endogenous $E_{2}$. Despite current findings, more studies are required to clarify the disruption of HPLG axis elicited by metals and spiked with xeno-estrogens in fish with matrotrophic viviparity.

\section{ACKNOWLEDGMENTS}

This study was supported by the Instituto Politécnico Nacional, SIP code 20150855. H.F. Olivares-Rubio is $\mathrm{PhD}$ student which receive scholarship from Consejo Nacional de Ciencia y Tecnología (CONACyT) and Becas de Estímulo Institucional de Formación de InvestigadoresInstituto Politécnico Nacional. A. Vega-López is an associate of the Program "Estímulos al Desempeño en Investigación and Comisión y Fomento de Actividades Académicas (Instituto Politécnico Nacional)" and a member of "Sistema Nacional de Investigadores (SNI)".

\section{REFERENCES}

Amutha C. and Subramanian P. (2013). Cadmium alters the reproductive endocrine disruption and enhancement of growth in the early and adult stages of Oreochromis mossambicus. Fish Physiol. Biochem. 39 (2), 351-361. DOI: $10.1007 / \mathrm{s} 10695-012-9704-3$

Aroua S., Maugars G., Jeng S. R., Chang C. F., Weltzien F. A., Rousseau K. and Dufour S. (2012). Pituitary gonadotropins FSH and LH are oppositely regulated by the activin/follistatin system in a basal teleost, the eel. Gen. Comp. Endocrinol. 175 (1), 82-91.

DOI: 10.1016/j.ygcen.2011.10.002

Bailhache T., Arazam A., Klungland H., Aleström P., Breton B. and Jego P. (1994). Localization of salmon gonadotropin-releasing hormone mRNA and peptide in the brain of Atlantic salmon and rainbow trout. J. Comp. Neurol. 347 (3), 444-454.

DOI: $10.1002 /$ cne. 903470310

Bradford M. (1976). A rapid and sensitive method for the quantitation of microgram quantities of protein utilizing the principle of protein-dye binding. Anal. Biochem. 72 (1-2), 248-254.

DOI: 10.1016/0003-2697(76)90527-3

Chang Z., Lu M., Lee K. W., Oh B. S., Bae M. J. and Park J. S. (2011). Influence of divalent metal ions on E2induced ER pathway in goldfish (Carassius auratus) hepatocytes. Ecotoxicol. Environ. Saf. 74 (8), 22332239. DOI: 10.1016/j.ecoenv.2011.07.024
Cheshenko K., Pakdel F., Segner H., Kah O. and Eggen R. L. (2008). Interference of endocrine disrupting chemicals with aromatase cyp 19 expression or activity, and consequences for reproduction of teleost fish. Gen. Comp. Endocrinol. 155 (1), 31-62.

DOI: 10.1016/j.ygcen.2007.03.005

Coumailleau P., Pellegrini E., Adrio F., Diotel N., CanoNicolau J., Nasri A., Vaillant C. and Kah O. (2015). Aromatase, estrogen receptors and brain development in fish and amphibians. Biochim. Biophys. Acta 1849 (2), 152-162.

DOI: 10.1016/j.bbagrm.2014.07.002

Crump K. L. and Trudeau V. L. (2009). Mercury-induced reproductive impairment in fish. Environ. Toxicol. Chem. 28 (5), 895-907. DOI: 10.1897/08-151.1

Diotel N., Le Page Y., Mouriec K., Tong S. K., Pellegrini E., Vaillant C., Anglade I., Brion F., Pakdel F., Chung B. C. and Kah O. (2010). Aromatase in the brain of teleost fish: expression, regulation and putative functions. Front. Neuroendocrinol. 31 (2), 172-192.

DOI: $10.1016 / j . y f r n e .2010 .01 .003$

Darbre P. D. (2006). Metallestrogens: an emerging class of inorganic xenestrogens with potential to add to the estrogenic burden of the human breast. J. Appl. Toxicol. 26 (3), 191-197. DOI: 10.1002/jat.1135

Falchuk K. H. and Montorzi M. (2001). Zinc physiology and biochemistry in oocytes and embryos. Biometals 14 (3), 385-395. DOI: 10.1023/A:1012994427351

Filby A. L., Neuparth T., Thorpe K. L., Owen R., Galloway T. S. and Tyler C. R. (2007). Health impacts of estrogens in the environment, considering complex mixture effects. Environ. Health Perspect. 115 (12), 1704-1710. DOI: $10.1289 /$ ehp. 10443

Folmar L. C., Hemmer M., Hemmer R., Bowman C., Kroll K. and Denslow N. D. (2000). Comparative estrogenicity of estradiol, ethynyl estradiol and diethylstilbestrol in an in vivo, male sheepshead minnow (Cyprinodon variegatus), vitellogenin bioassay. Aquat. Toxicol. 49 (1-2), 77-88. DOI: 10.1016/S0166-445X(99)00076-4

Huang G. Y., Ying G. G., Liang Y. Q., Liu S. S. and Liu Y. S. (2014). Expression patterns of metallothionein, cytochrome P450 1A and vitellogenin genes in western mosquitofish (Gambusia affinis) in response to heavy metals. Ecotoxicol. Environ. Saf. 105, 97-102.

DOI: 10.1016/j.ecoenv.2014.04.012

Janz D. M. and Weber L. P. (2000). Endocrine system. In: The laboratory fish: The handbook of experimental animals (G. K. Ostrander, Ed.). Academic Press, San Diego, USA, pp. 415-449.

Karigo T., Aikawa M., Kondo C., Abe H., Kanda S. and Oka Y. (2014). Whole brain-pituitary in vitro preparation of the transgenic medaka (Oryzias latipes) as a tool for analyzing the differential regulatory mechanisms of 
LH and FSH release. Endocrinology 155 (2), 536-547. DOI: $10.1210 /$ en.2013-1642

Kazeto Y., Place A. R. and Trant J. M. (2004). Effects of endocrine disrupting chemicals onexpression of cyp 19 genes in zebrafish (Danio rerio) juveniles. Aquat. Toxicol. 69 (1), 25-34.

DOI: $10.1016 /$ j.aquatox.2004.04.008

Khan I. A. and Thomas P. (2000). Lead and Aroclor 1254 disrupt reproductive neuroendocrine function in Atlantic croaker. Mar. Environ. Res. 50 (1-5), 119-123. DOI: 10.1016/S0141-1136(00)00108-2

Klein D., Wan Y. Y., Kamyab S., Okuda H. and Sokol R. Z. (1994). Effects of toxic levels of lead on gene regulation in the male axis: Increase in messenger ribonucleic acid and intracellular stores of gonadotrophs within the central nervous system. Biol. Reprod. 50 (4), 802-811. DOI: 10.1095/biolreprod50.4.802

Lange A., Katsu Y., Ichikawa R., Paull G. C., Chidgey L. L., Coe T. S., Iguchi T. and Tyler C. R. (2008). Altered sexual development in roach (Rutilus rutilus) exposed to environmental concentrations of the pharmaceutical 17alpha-ethinylestradiol and associated expression dynamics of aromatases and estrogen receptors. Toxicol. Sci. 106 (1), 113-123. DOI: 10.1093/toxsci/kfn151

Łuszczek-Trojnar E., Drąg-Kozak E., Szczerbik P., Socha M. and Popek W. (2014). Effect of long-term dietary lead exposure on some maturation and reproductive parameters of a female Prussian carp (Carassius gibelio B.). Environ. Sci. Pollut. Res. Int. 21 (4), 2465-2478. DOI: $10.1007 / \mathrm{s} 11356-013-2184-\mathrm{x}$

Olivares-Rubio H. F., Dzul-Caamal R., Gallegos-Rangel M. E., Madera-Sandoval R. L., Domínguez-López M. L., García-Latorre E. and Vega-López A. (2015). Relationship between biomarkers and endocrine-disrupting compounds in wild Girardnichthys viviparus from two lakes with different degrees of pollution. Ecotoxicology 24 (3), 664-685. DOI: 10.1007/s10646-014-1414-4

Palacios O., Atrian S. and Capdevila M. (2011). Zn- and $\mathrm{Cu}$-thioneins: a functional classification for metallothioneins? J. Biol. Inorg. Chem. 16, 991-1009.

DOI: $10.1007 / \mathrm{s} 00775-011-0827-2$

Pedersen K. L., Pedersen S. N., Højrup P., Andersen J. S., Roepstorff P., Knudsen J. and Depledge M. H. (1994). Purification and characterization of a cadmiuminduced metallothionein from the shore crab Carcinus maenas (L.) Biochem. J. 297 (3), 609-614.

DOI: $10.1042 / b j 2970609$

Rempel M. A. and Schlenk D. (2008). Effects of environmental estrogens and antiandrogens on endocrine function, gene regulation, and health in fish. Int. Rev. Cell Mol. Biol. 267, 207-252.

DOI: $10.1016 /$ S1937-6448(08)00605-9

Rose J., Holbech H., Lindholst C., Nørum U., Povlsen A.,
Korsgaard B. and Bjerregaard P. (2002). Vitellogenin induction by $17 \mathrm{~b}$-estradiol and 17a-ethinylestradiol in male zebrafish (Danio rerio). Comp. Biochem. Physio. Part C 131 (4), 531-539. DOI: $10.1016 / \mathrm{S} 1532-0456(02) 00035-2$

SAGARPA (2001). Norma Oficial Mexicana NOM-062ZOO-1999 Especificaciones técnicas para la producción, cuidado y el uso de animales de laboratorio. Diario Oficial de la Federación. 22 de agosto de 2001. Sanchez W., Burgeot T. and Porcher J. M. (2012). A novel "Integrated Biomarker Response" calculation based on reference deviation concept. Environ. Sci. Pollut. Res. Int. 20 (5), 2721-2725.

DOI: $10.1007 / \mathrm{s} 11356-012-1359-1$

Sarkar S., Bhattacharya D., Juin S.K. and Nath P. (2014). Biological properties of Indian walking catfish (Clarias batrachus) (L.) gonadotropins in female reproduction. Fish Physiol. Biochem. 40 (6), 1849-1861.

DOI: $10.1007 / \mathrm{s} 10695-014-9973-0$

Sears M. E. (2013). Chelation: harnessing and enhancing heavy metal detoxification-a review. Scientific World J. 2013, 219840. DOI: 10.1155/2013/219840

Sedeño-Díaz J. E. and López-López E. (2009). Threatened fishes of the world: Girardinichthys viviparus (Bustamante 1837) (Cyprinodontiformes: Goodeidae). Environ. Biol. Fish 84 (1), 11-12.

DOI: $10.1007 / \mathrm{s} 10641-008-9380-4$

Shanle E. K. and Xu W. (2011). Endocrine disrupting chemicals targeting estrogen receptor signaling: identification and mechanisms of action. Chem. Res. Toxicol. 24 (1), 6-19. DOI: 10.1021/tx100231n

Simmons D. B., McMaster M. E., Reiner E. J., Hewitt L. M., Parrott J. L., Park B. J., Brown S. B. and Sherry J. P. (2014). Wild fish from the Bay of Quinte Area of Concern contain elevated tissue concentrations of PCBs and exhibit evidence of endocrine-related health effects. Environ. Int. 66, 124-137.

DOI: 10.1016/j.envint.2014.01.009

Sumpter J. P. and Jobling S. (1995). Vitellogenesis as a biomarker for estrogenic contamination of the aquatic environment. Environ. Health Perspect. 103 (7), 173178. DOI: $10.2307 / 3432529$

Swanson P., Dickey J. T. and Campbell B. (2003). Biochemistry and physiology of fish gonadotropins. Fish Physiol. Biochem. 28 (1), 53-59.

DOI: 10.1023/B:FISH.0000030476.73360.07

Szczerbik P., Mikołajczyk T., Sokołowska-Mikołajczyk M., Socha M., Chyb J. and Epler P. (2006). Influence of long-term exposure to dietary cadmium on growth, maturation and reproduction of goldfish (subspecies: Prussian carp Carassius auratus gibelio B.). Aquat. Toxicol. 77 (2), 126-135.

DOI: $10.1016 /$ j.aquatox.2005.11.005 
Thompson E. D., Mayer G. D., Balesaria S., Glover C. N., Walsh P. J. and Hogstrand C. (2003). Physiology and endocrinology of zinc accumulation during the female squirrelfish reproductive cycle. Comp. Biochem. Physiol. A Mol. Integr. Physiol. 134 (4), 819-28. DOI: 10.1016/S1095-6433(03)00015-1

Thompson E. D., Mayer G. D., Glover C. N., Capo T., Walsh P. J. and Hogstrand C. (2012). Zinc hyperaccumulation in squirrelfish (Holocentrus adscenscionis) and its role in embryo viability. PLoS One 7 (10), e46127. DOI: 10.1371/journal.pone.0046127

Van den Belt K., Verheyen R. and Witters H. (2003). Comparison of vitellogenin responses in zebrafish and rainbow trout following exposure to environmental estrogens. Ecotoxicol. Environ. Saf. 56 (2), 271-281. DOI: 10.1016/S0147-6513(03)00004-6

Vega-López A., Martínez-Tabche L., Domínguez-López M. L., García-Latorre E., Ramón-Gallegos E. and García-Gasca A. (2006) Vitellogenin induction in the endangered goodeid fish Girardinichthys viviparus: vitellogenin characterization and estrogenic effects of polychlorinated biphenyls. Comp. Biochem. Physiol. C Toxicol. Pharmacol. 142 (3-4), 356-364.

DOI: 10.1016/j.cbpc.2005.11.009

Vega-López A., Ortiz-Ordóñez E., Uría-Galicia E., Mendoza-Santana E. L., Hernández-Cornejo R., Atondo-Mexia R., García-Gasca A., García-Latorre E. and Domínguez-López M. L. (2007). The role of vitellogenin during gestation of Girardinichthys viviparus and Ameca splendens; two goodeid fish with matrotrophic viviparity. Comp. Biochem. Physiol. A Mol. Integr. Physiol. 147 (3), 731-742.

DOI: $10.1016 /$ j.cbpa.2006.10.039
Vega-López A., Ayala-López G., Posadas-Espadas B. P., Olivares-Rubio H. F., and Dzul-Caamal R. (2013). Relations of oxidative stress in freshwater phytoplankton with heavy metals and polycyclic aromatic hydrocarbons. Comp. Biochem. Physiol. A Mol. Integr. Physiol. 165 (4), 498-507. DOI: 10.1016/j.cbpa.2013.01.026

Vetillard A. and Bailhache T. (2005). Cadmium: An endocrine disrupter that affects gene expression in the liver and brain of juvenile rainbow trout. Biol. Reprod. 72 (1), 119-126. DOI: 10.1095/biolreprod.104.029520

Vosges M., Le Page Y., Chung B-C., Combarnous Y., Porcher J-M., Kah O. and Brion F. (2010). 17alphaethinylestradiol disrupts the ontogeny of the forebrain GnRH system and the expression of brain aromatase during early development of zebrafish. Aquat. Toxicol. 99 (4), 479-491. DOI: 10.1016/j.aquatox.2010.06.009

Wang L., Cai Y. Q., He B., Yuan C. G., Shen D. Z., Shao J. and Jiang G. B. (2006). Determination of estrogens in water by HPLC-UV using cloud point extraction. Talanta 70 (1), 47-51. DOI: $10.1016 /$ j.talanta.2006.01.013

Yan Z., Lu G., Liu J. and Jin S. (2012). An integrated assessment of estrogenic contamination and feminization risk in fish in Taihu Lake, China. Ecotoxicol. Environ. Saf. 84, 334-340. DOI: 10.1016/j.ecoenv.2012.08.010 Yaron Z., Gur G., Melamed P., Rosenfeld H., Elizur A. and Levavi-Sivan B. (2003). Regulation of fish gonadotropins. Int. Rev. Cytol. 225, 131-185. DOI: 10.1016/S0074-7696(05)25004-0

Yuan Y., Jiang C. Y., Xu H., Sun Y., Hu F. F., Bian J. C., Liu X. Z., Gu J. H. and Liu Z. P. (2013). Cadmiuminduced apoptosis in primary rat cerebral cortical neurons culture is mediated by a calcium signaling pathway. PLoS One 8 (5), e64330.

DOI: 10.1371 /journal.pone. 0064330 